\title{
SOME NOTES ON AN EPITHET OF ANUBIS FROM THE ANCIENT EGYPTIAN COFFIN OF MERNEBY IN BRATISLAVA*
}

\author{
Dušan MAGDOLEN \\ Institute of Oriental Studies, Slovak Academy of Sciences \\ Klemensova 19, 81364 Bratislava, Slovakia \\ kaorduma@savba.sk
}

\begin{abstract}
This article deals with the interpretation of an ideographically written epithet of Anubis and its possible phonetic transliteration and reading. The list of epithets of Anubis occurs in the inner inscriptions of the ancient Egyptian coffin of Merneby in Bratislava. They were written on the bottom of the coffin lid as well as the coffin trough. In regard to the specific role of Anubis in ancient Egyptian religion it is argued that the epithet in question, partly written in an abbreviated ideographical form, may identify Anubis as a lord $(n b)$ of the divine sancturary or shrine ( $s t y t$ or $k 3 r)$, purification tent $(i b w)$, burial $(k r s t)$, coffin $(k r s w)$ or chest $(h n)$.
\end{abstract}

Keywords: coffin, Merneby, inner inscriptions, palaeography, epithet, Anubis

In volumes 27 and 28 of this journal I have published two articles focused on the hieroglyphic inscriptions preserved inside the ancient Egyptian coffin in the Slovak National Museum in Bratislava. ${ }^{1}$ The inner inscriptions ascribe this coffin to a man called Merneby. The textual composition of the inner inscriptions also includes $h t p-d i-n s w t$ formulae written in horizontal lines in black ink on the bottom of the coffin lid and the trough. In both cases the offering formulae start from line 1 occurring near the top of the head and continue down to the middle of the coffin. The text is written in the so-called

* This work was supported thanks to the grant project No. VEGA 2/0028/18.

1 MAGDOLEN, D. The Ancient Egyptian Coffin in the Slovak National Museum: Inscriptions on the Interior Surface of the Lid. In Asian and African Studies, 2018, Vol. 27, No. 2, pp. 143-191, 263-273; MAGDOLEN, D. The Ancient Egyptian Coffin in the Slovak National Museum: Inscriptions on the Interior Surface of the Trough. In Asian and African Studies, 2019, Vol. 28, No. 2, pp. 270-331, 429-440. 
cursive hieroglyhs, a specific script generally used by the scribes for writing religious texts, such as the Book of the Dead, and decorating burial equipment including coffins, papyri, etc. ${ }^{2}$ From the point of view of palaeography it seems that the texts written inside the coffin reveal a very similar or even the same handwriting, in other words, the inscriptions inside the coffin lid and trough were very probably written by one and the same person. ${ }^{3}$

The above-mentioned offering formulae comprise the list of divine names, including the god Anubis, accompanied by their epithets. In the case of the coffin lid the name of the god Anubis and his epithets start to appear from line 10 onwards, and in the case of the coffin trough the name of Anubis with epithets is first attested in line 11 (see tables 1 and 2 below). The names and epithets of Anubis occur altogether in three lines in both parts of the coffin. Line 12 of the coffin lid (see figure 1) and line 13 of the coffin trough (see figure 2) include the epithet of Anubis partly written ideographically starting with the noun $n b$ "lord". This word is followed by a hieroglyphic sign which

I have transcribed using the conventions of Gardiner's sign-list, namely

(Gardiner O20) for the sign appearing on the lid, and $\underline{\square}$ (Gardiner O18) for the sign written in the trough..$^{5}$ In both cases, these signs belong to the category referring to buildings, parts of buildings, etc. ${ }^{6}$ The word is evidently written ideographically without any phonetic complements and it ends in both cases with the sign 5 (Gardiner A40). ${ }^{7}$ However, in the case of the sign Gardiner

${ }^{2}$ LUCARELLI, R. Cursive Hieroglyphs in the Book of the Dead. In DAVIES, V., LABOURY, D. (eds.). The Oxford Handbook of Egyptian Epigraphy and Palaeography, (sine pagina).

${ }^{3}$ Cf. MAGDOLEN, D. The Ancient Egyptian Coffin in the Slovak National Museum: Inscriptions on the Interior Surface of the Lid. In Asian and African Studies, 2018, Vol. 27, No. 2, pp. 166-187, 305-327; MAGDOLEN, D. The Ancient Egyptian Coffin in the Slovak National Museum: Inscriptions on the Interior Surface of the Trough. In Asian and African Studies, 2019, Vol. 28, No. 2, pp. 305-327, 429-439.

${ }^{4}$ The masculine noun definitely referring to Anubis was written with the meaningless $t$ sign, which was typical of the Late Period texts, see JANSEN-WINKELN, K. Spätmittelägyptische Grammatik der Texte der 3. Zwischenzeit, pp. 24-26, 78.

${ }^{5}$ See Note 1.

${ }^{6}$ GARDINER, A. H. Egyptian Grammar, p. 492.

${ }^{7}$ The seated god depicted in this word occurring in the coffin lid was evidently written without the divine beard below the chin. Cf. the palaeographic table in MAGDOLEN, D. The Ancient Egyptian Coffin in the Slovak National Museum: Inscriptions on the Interior Surface of the Lid. In Asian and African Studies, 2018, Vol. 27, No. 2, p. 167. 
Some Notes on an Epithet of Anubis from the Ancient Egyptian Coffin ...

O20 occurring on the coffin lid, the sign of the seated god is preceded by three strokes arranged horizontally I I I (Gardiner Z2). ${ }^{8}$ I have transliterated and read the epithet of Anubis from the coffin lid as $n b s t y t$ and the one from the coffin trough as $n b k 3 r$, and both versions should refer to Anubis as "lord of the sanctuary" or "lord of the shrine".

However, there are some features that are interesting from various points of view and should be noted briefly and discussed in a wider context, and some of these may entail a revision of the previous reading. As for the palaeographic description of both signs it can be said that there are some similar as well as different characteristics in their shapes. Their outlines resemble the state shrines or sanctuaries of Upper and Lower Egypt per-wer $(\underline{\square}$ ) and per-nw (lll) respectively. ${ }^{9}$ The signs in the epithet discussed are both rectangular with the vaulted or vault-like roof and written with two horizontally running short lines overhanging on both sides under the roof (see figures 1 and 2). In both cases, a small mark indicated by two short vertical strokes depicted at the bottom within the sign on the lid and one stroke (or originally two?) in the case of the sign on the trough, appears to be placed inside each of these two signs. The difference between the two signs discussed consists in the shape of the uppermost part depicting the vaulted roof of a shrine or chapel. It seems that the curvature of the roof in the sign on the lid is symmetrical, while that in the sign on the trough is asymmetrical. Another smaller difference consists in the verticality of signs. The sign on the lid seems to be a little more vertical compared with the one on the trough. However, from the palaeographic point of view the aspect of the symmetry of the roof in the case of the sign on the lid as well as the parameter of verticality may be inaccurate and misleading because of the specific features and individual characteristics of the handwriting of the scribe responsible for writing the inscriptions inside the coffin. ${ }^{10}$ However, small variations in the

This sign was transcribed as seated woman (Gardiner B1) in the publication from the 1980s VERNER, M. Altägyptische Särge in den Museen und Sammlungen der Tschechoslowakei. Corpus Antiquitatum Aegyptiacarum, Lieferung 1, p. 19.

${ }^{8}$ They usually indicate the plural of a noun but, sometimes they were used without this function in inscriptions from the Late Period. For the so-called false plural in the Late Period texts see JANSEN-WINKELN, K. Spätmittelägyptische Grammatik der Texte der 3. Zwischenzeit, pp. 24, 92-94.

${ }^{9}$ ARNOLD, D. The Monuments of Egypt, pp. 173-174.

10 The palaeographic table of the inscriptions preserved inside the lid and trough show numerous differences and similarities in the case of even the same signs. See MAGDOLEN, D. The Ancient Egyptian Coffin in the Slovak National Museum: Inscriptions on the Interior Surface of the Lid. In Asian and African Studies, 2018, Vol. 27, No. 2, pp. 166-187; MAGDOLEN, D. The Ancient Egyptian Coffin in the Slovak 
shape of individual signs do not necessarily mean different scribes. In fact both signs may, theoretically, identify and express one and the same word. In other words, one word with the same meaning would occur on the lid and trough as an epithet included among the others referring to Anubis, even if written a little differently. Indirect evidence may come from the repeated occurrence and reuse of some epithets of Anubis in this coffin, such as $n b t 3 \underline{d s r}$ and tpy $\underline{d} w . f$. They were mentioned twice in the coffin, i.e. on the lid as well as trough (see nos. 1 and 2 in table 1 and nos. 3 and 4 in table 2). Whatever both signs under discussion may represent, it should be emphasized that the occurrence of the sign depicting the seated god $(5)$ used as the determinative in both words indicates that the structure or object may have been of divine character and associated either with Anubis himself or the deceased person identified with the god Osiris (depending on the true meaning and translation of the word).

When searching for a more precise identification of the discussed epithet of Anubis appearing in the coffin of Merneby, it will be useful to present some other variant readings and meanings of words written by one of both hieroglyphic signs (Gardiner O18 and Gardiner O20) sometimes accompanied by phonetic complements, but having different meanings. All the evidence comes from a funerary context and refers directly or indirectly to Anubis and his role in the funerary religion and religious practice of the ancient Egyptians. ${ }^{11}$

Both signs occurring in the epithet were transcribed and interpreted in previous editions of mine in the context of the architecture as divine shrine or sanctuary. In this context, however, another phonetic interpretation may be possible. In the shape of the signs Gardiner O18 and Gardiner O20 one can also see a structure built from light and organic materials and utilised for practical purposes, namely, burial ceremonies associated with the mumification and the embalming process of the deceased person. According to ancient Egyptian mythology, the god Anubis was known as the embalmer of the body of Osiris. In ancient Egypt the priests responsible for embalming the body of the deceased person identified themselves with the god Anubis and may have worn the jackal-headed mask. In this context the ideographically written word appearing in the epithet of Anubis and determined by the picture of a seated god may also

National Museum: Inscriptions on the Interior Surface of the Trough. In Asian and African Studies, 2019, Vol. 28, No. 2, pp. 305-327; Cf. MÖLLER, G. Hieratische Paläographie, Bde I-IV, passim and POLIS S. Methods, Tools and Perspectives of Hieratic Palaeography. In DAVIES, V., LABOURY, D. (eds.). The Oxford Handbook of Egyptian Epigraphy and Palaeography, (sine pagina).

${ }^{11}$ On Anubis see LEITZ, Ch. Lexikon der ägyptischen Götter und Götterbezeichnungen, Vol. I, pp. 390-394. 
Some Notes on an Epithet of Anubis from the Ancient Egyptian Coffin ...

be interpreted as a structure referring to the purification tent in which the mummification rituals were performed and where the rebirth and afterlife of the deceased person, transformed into a divine being, began in a new form. There is Old Kingdom textual evidence mentioning a structure known as $i b u .^{12}$ This word written phonetically and determined by the sign the 5th Dynasty inscription coming from the tomb of Washptah. ${ }^{13}$ According to some scholars, ${ }^{14}$ the purification tent $i b u$ may be just another term for $z h n t r$ "divine booth" also known and mentioned in the list of epithets of Anubis (see no. 2 in table 2). On the other hand, it should be noted that the sign also be found in the word $\underline{h} \underline{d}$ with the meaning "chapel", referring to an architectural structure associated with a divine being. ${ }^{15}$

The word belonging to the epithet under discussion may theoretically also have another phonetic value and could be different from the architectural context, but still referring to Anubis as the deity inherently associated with death, burial and the afterlife. This word has the consonantal root consisting of the signs transliterated as $k r s$, and can be used as a noun with the meaning "burial" $(k r s t)^{16}$ or "coffin" $(k r s w) .{ }^{17}$ Variant writings of these nouns appearing in contemporary inscriptions are attested in their abbreviated forms as well. In these inscriptions the sign $\square$ can occur as the divine epithet "lord of burial" and/or "lord of the coffin" 18 referring to Anubis. ${ }^{19}$

${ }^{12}$ FAULKNER, R. O. A Concise Dictionary of Middle Egyptian, p. 15.

${ }^{13}$ GRDSELOFF, B. Das ägyptische Reinigungszelt, p. 1.

${ }^{14}$ HAYS, H. M. Funerary Rituals (Pharaonic Period). In UCLA Encyclopedia of Egyptology, 2010 [online] Available from http://digital2.library.ucla.edu/viewItem.do? ark $=21198 / \mathrm{zz} 001 \mathrm{nf} 65 \mathrm{w}$. For a discussion focused on the purification tent and funerary rituals see also ALTENMÜLLER, H. Die Bedeutung der „Gotteshalle des Anubis“ im Begräbnisritual. In Jaarbericht Ex Oriente Lux, 1967 - 1968, Vol. 20, pp. 307-317; HOFFMEIER, J. K. The Possible Origins of the Tent of Purification in the Egyptian Funerary Cult. In Studien zur Altägyptischen Kultur, Bd. 9, 1981, pp. 167-177.

${ }^{15}$ ERMAN, A., GRAPOW, H. Wörterbuch, Bd. 3, p. 209.

${ }^{16}$ ERMAN, A., GRAPOW, H. Wörterbuch, Bd. 5, p. 64; FAULKNER, R. O. A Concise Dictionary of Middle Egyptian, p. 281.

${ }^{17}$ ERMAN, A., GRAPOW, H. Wörterbuch, Bd. 5, p. 65; FAULKNER, R.O. A Concise Dictionary of Middle Egyptian, p. 281.

${ }^{18}$ GARDINER, A. H., SETHE, K. Egyptian Letters to the Dead. The Egypt Exploration Society, p. 31 I/1.; DE BUCK, A. The Egyptian Coffin Texts, Vol. VII, p. 137, Spell 936a and FAULKNER, R. O. Ancient Egyptian Coffin Texts, Vol. III, p. 70; 
Another alternative variant in our discussion, focused on palaeography and the possible phonetic transliteration of the ideographically written epithet of Anubis in the inner inscriptions of the Bratislava coffin of Merneby, concerns the word $h n$ translated as "chest" or "box" ${ }^{20}$ Besides the meaning $n b h n$ "lord of the chest" ${ }^{21}$ some surviving textual evidence mentions directly $h n$ Inpw "chest of Anubis". 22 This word can be determined by various signs including that of Gardiner O18 and may be translated with the meaning of "coffin" as well. ${ }^{23}$ The convex uppermost part of the hieroglyphic signs Gardiner O18 and Gardiner O20 may theoretically also reflect the shape of the vaulted lid of the outermost wooden coffin since the mummified body of the deceased person could have been placed in more than one coffin. ${ }^{24}$ The well-known 25 th Dynasty coffin of Djed-Djehuty-Iuef-Ankh from the Ashmolean Museum in Oxford provides spectacular material evidence of this kind with a statuette of a jackal deity recumbent on top of the outermost lid (see figure 3 ).

All the possible phonetic forms of the epithet under discussion presented above should be taken into consideration in the discussion dealing with the interpretation of this part of the text from the coffin of Merneby. They are reliably attested from surviving contemporary textual as well as iconographic and archaeological evidence. A number of specific terms referring to funerary architecture, burial equipment and mortuary ceremonies associated with Anubis

MARIETTE A. Les Mastabas de l'Ancien Empire, pp. 120 (C4), 278-279 (D39), 283-4 (D40), 295 (D42).

${ }^{19}$ Cf. LEITZ, Ch. Lexikon der ägyptischen Götter und Götterbezeichnungen, Vol. III., pp. 761-762.

${ }^{20}$ ERMAN, A., GRAPOW, H. Wörterbuch, Bd. 2, pp. 491-492; FAULKNER, R. O. A Concise Dictionary of Middle Egyptian, p. 158.

${ }^{21}$ ROEDER, G. Naos (CGAE 70043), p. 141, § 510; DARESSY, M. G. Cercueils des cachettes royales, pp. 72 (CGAE 61027) and 98 (CGAE 61029); SIMPSON, W. K. A Statuette of a Devotee to Seth. In Journal of Egyptian Archaeology, 1976, Vol. 62, p. 42, Pl. VIIIA; GOMAÀ, F. Särge und andere Funde aus der Nekropole der Falkenstadt. In Mitteilungen des Deutschen Archäologischen Instituts Abteilung Kairo, Bd. 57, p. 45. On the association with the Anubeion at Saqqara see LAPP, G. Die Stelenkapelle des Kmz aus der 13. Dynastie. In Mitteilungen des Deutschen Archäologischen Instituts Abteilung Kairo, 1994, Bd. 50, pp. 235, 252; KEES, H. Der sogenannte oberste Vorlesepriester. In Zeitschrift für Ägyptische Sprache und Altertumskunde, Bd. 87, p. 132; VANDIER, J. Le Papyrus Jumilhac, p. 154, n. 123.

${ }^{22}$ ERMAN, A., GRAPOW, H. Wörterbuch, Bd. 2, p. 491; ERMAN, A., GRAPOW, H. Wörterbuch, Bd. 2 (Die Belegstellen), p. 476.

${ }^{23}$ HANNIG, R. Großes Handwörterbuch Ägyptisch - Deutsch, pp. 493-494.

${ }^{24}$ For the archaeological evidence see MORET, A. Sarcophages de l'époque bubastite à l'époque saïte, Pls. 1-39. 
Some Notes on an Epithet of Anubis from the Ancient Egyptian Coffin ...

emphasize the key role of Anubis in ancient Egyptian religion and the specific context in which this deity can appear, i.e. death, burial and the afterlife.

\section{REFERENCES}

ALTENMÜLLER, Hartwig. Die Bedeutung der „Gotteshalle des Anubis“ im Begräbnisritual. In Jaarbericht Ex Oriente Lux, 1967 - 1968, Vol. 20, pp. 307-317.

ARNOLD, Dieter. The Monuments of Egypt. London: I. B. Tauris 2009.

DARESSY, Georges M. Cercueils des cachettes royales. CGAÉ, nos. 6100161044. Le Caire 1909.

De BUCK, Adriaan. The Egyptian Coffin Texts, Vol. VII. Chicago: The University of Chicago Press, 1961.

ERMAN, Adolf, GRAPOW, Hermann. Wörterbuch der aegyptischen Sprache. Bde. 1-5. Leipzig: J. C. Hinrichs'sche Buchhandlung, 1926 - 1931.

FAULKNER, Raymond O. Ancient Egyptian Coffin Texts, Vol. III, Aris and Phillips, Warminster, 1978

FAULKNER, Raymond O. A Concise Dictionary of Middle Egyptian. Oxford: Griffith Institute, 1996.

GARDINER, Allan H. Egyptian Grammar Being and Introduction to the Study of Hieroglyphs. Third Edition, Revised. Oxford: Griffith Institute, 1982.

GARDINER, Allan H., SETHE, Kurt. H. Egyptian Letters to the Dead. The Egypt Exploration Society, London, 1928.

GOMAÀ, Farouk. Särge und andere Funde aus der Nekropole der Falkenstadt. In Mitteilungen des Deutschen Archäologischen Instituts Abteilung Kairo, 2001, Bd. 57, pp. 35-57.

GRDSELOFF, Bernhard. Das ägyptische Reinigungszelt. Le Caire 1941.

HANNIG, Rainer. Großes Handwörterbuch Ägyptisch - Deutsch. Darmstadt: WBG, Philipp von Zabern Verlag, 2015.

HAYS, Harold. M. Funerary Rituals (Pharaonic Period). In DIELEMAN Jacco, WENDRICH Willeke (eds.). UCLA Encyclopedia of Egyptology, 2010 [online] Available from http://digital2.library.ucla.edu/viewItem.do?ark= 21198/zz001nf65w.

HOFFMEIER, James K. The Possible Origins of the Tent of Purification in the Egyptian Funerary Cult. In Studien zur Altägyptischen Kultu, Bd. 9, 1981, pp. 167-177.

JANSSEN-WINKELN, Karl. Spätmittelägyptische Grammatik der Texte der 3. Zwischenzeit. Ägypten und Altes Testament, Bd 34. Wiesbaden: Harrassowitz Verlag, 1996. 
KEES, Hermann. Der sogenannte oberste Vorlesepriester. In Zeitschrift für Ägyptische Sprache und Altertumskunde, 1962, 87, pp. 119-139.

LAPP, Günther. Die Stelenkapelle des Kmz aus der 13. Dynastie in Mitteilungen des Deutschen Archäologischen Instituts Abteilung Kairo, 1994, Bd. 50, pp. 231-252.

LUCARELLI, Rita. Cursive Hieroglyphs in the Book of the Dead. In DAVIES, Vanessa, LABOURY, Dimitri (eds.). The Oxford Handbook of Egyptian Epigraphy and Palaeography. Oxford: Oxford Univesity Press, 2020.

LEITZ, Christian (ed.). Lexikon der ägyptischen Götter und Götterbezeichnungen. Bände 1-8. Orientalia Lovaniensia Analecta (Bde. 110-129). Leuven: Peeters Publishers, 2002 - 2003.

MAGDOLEN, Dušan. The Ancient Egyptian Coffin in the Slovak National Museum: Inscriptions on the Interior Surface of the Lid. In Asian and African Studies, 2018, Vol. 27, No. 2, pp. 143-191, 263-273.

MAGDOLEN, Dušan. The Ancient Egyptian Coffin in the Slovak National Museum: Inscriptions on the Interior Surface of the Trough. In Asian and African Studies, 2019, Vol. 28, No. 2, pp. 270-331, 429-440.

MARIETTE, Auguste. Les Mastabas de l'Ancien Empire. Paris, 1885.

MORET, Alexandre M. Sarcophages de l'époque bubastite à l'époque saïte. CGAÉ 41001-40041. Le Caire, 1913

MÖLLER, Georg. Hieratische Paläographie I-IV. Leipzig: J. C. Hinrichs'sche Buchhandlung, 1909.

POLIS S. Methods, Tools and Perspectives of Hieratic Palaeography. In DAVIES, Vanessa, LABOURY, Dimitri (eds.). The Oxford Handbook of Egyptian Epigraphy and Palaeography. Oxford Univesity Press, 2020.

ROEDER, Günther. Naos. In CGAÉ, Nr. 70001-70050. Leipzig: Breitkopf \&Härtel, 1914.

SIMPSON, William. K. A Statuette of a Devotee to Seth. In Journal of Egyptian Archaeology, 1976, Vol. 62, pp. 41-44, Pl. VIIIA.

VANDIER, Jacques. Le Papyrus Jumilhac. Paris: CNRS, 1961.

VERNER, Miroslav. Altägyptische Särge in den Museen und Sammlungen der Tschechoslowakei. Corpus Antiquitatum Aegyptiacarum, Lieferung 1. Universita Karlova: Praha, 1982. 
Table 1. Names and epithets of Anubis occurring in the inner inscriptions of the lid.

\begin{tabular}{|c|c|c|}
\hline Sequence & Hieroglyphic Transcription & Occurrence \\
\hline 1 & 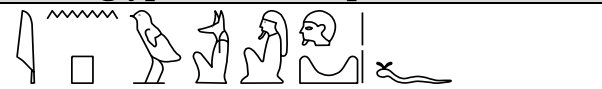 & Line 10 \\
\hline 2 & $\rightleftharpoons \stackrel{\sim}{\sim}$ & Lines 10/11 \\
\hline 3 & $d_{\square}^{m m}$ of & Line 11 \\
\hline 4 & 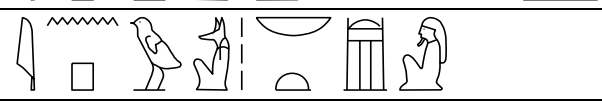 & Lines $11 / 12$ \\
\hline 5 & 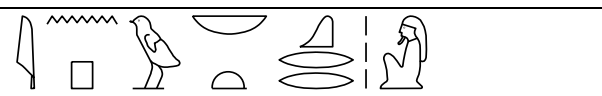 & Line 12 \\
\hline 6 & 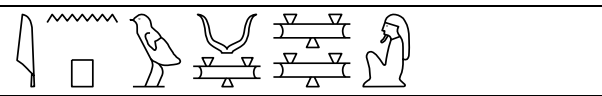 & Line 13 \\
\hline
\end{tabular}

Table 2. Names and epithets of Anubis occurring in the inner inscriptions of the trough.

\begin{tabular}{|c|c|c|}
\hline Sequence & Hieroglyphic Transcription & Occurrence \\
\hline 1 & 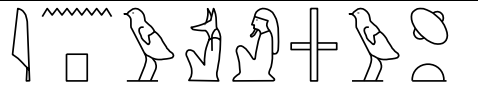 & Line 11 \\
\hline 2 & 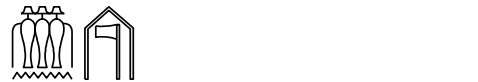 & Line 11 \\
\hline 3 & 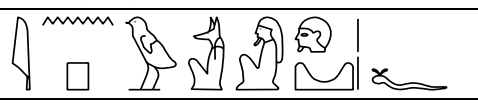 & Lines $11 / 12$ \\
\hline 4 & 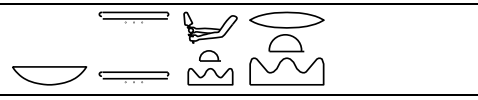 & Line 12 \\
\hline 5 & 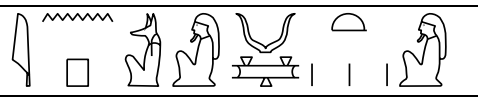 & Lines $12 / 13$ \\
\hline 6 & 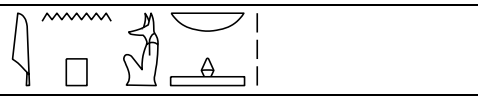 & Line 13 \\
\hline 7 & 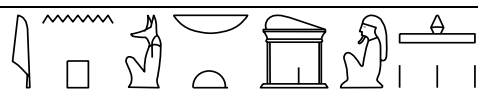 & Line 13 \\
\hline
\end{tabular}




\section{Illustrations}

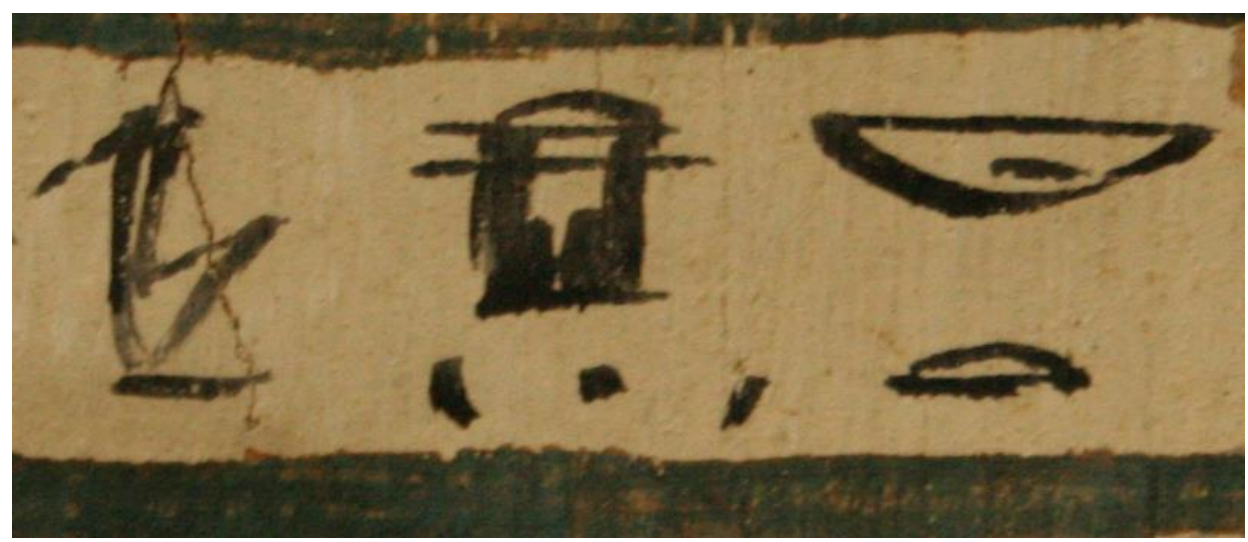

Figure 1. The epithet written from right to left inside the coffin lid (photo by D. Magdolen).

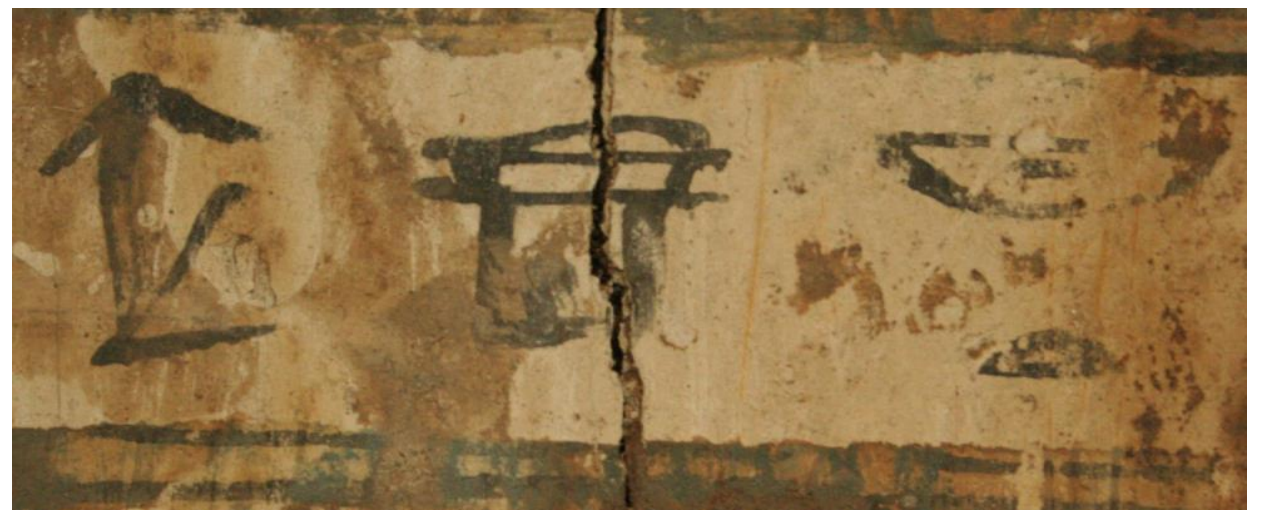

Figure 2. The epithet written from right to left inside the coffin trough (photo by D. Magdolen). 
Some Notes on an Epithet of Anubis from the Ancient Egyptian Coffin ...

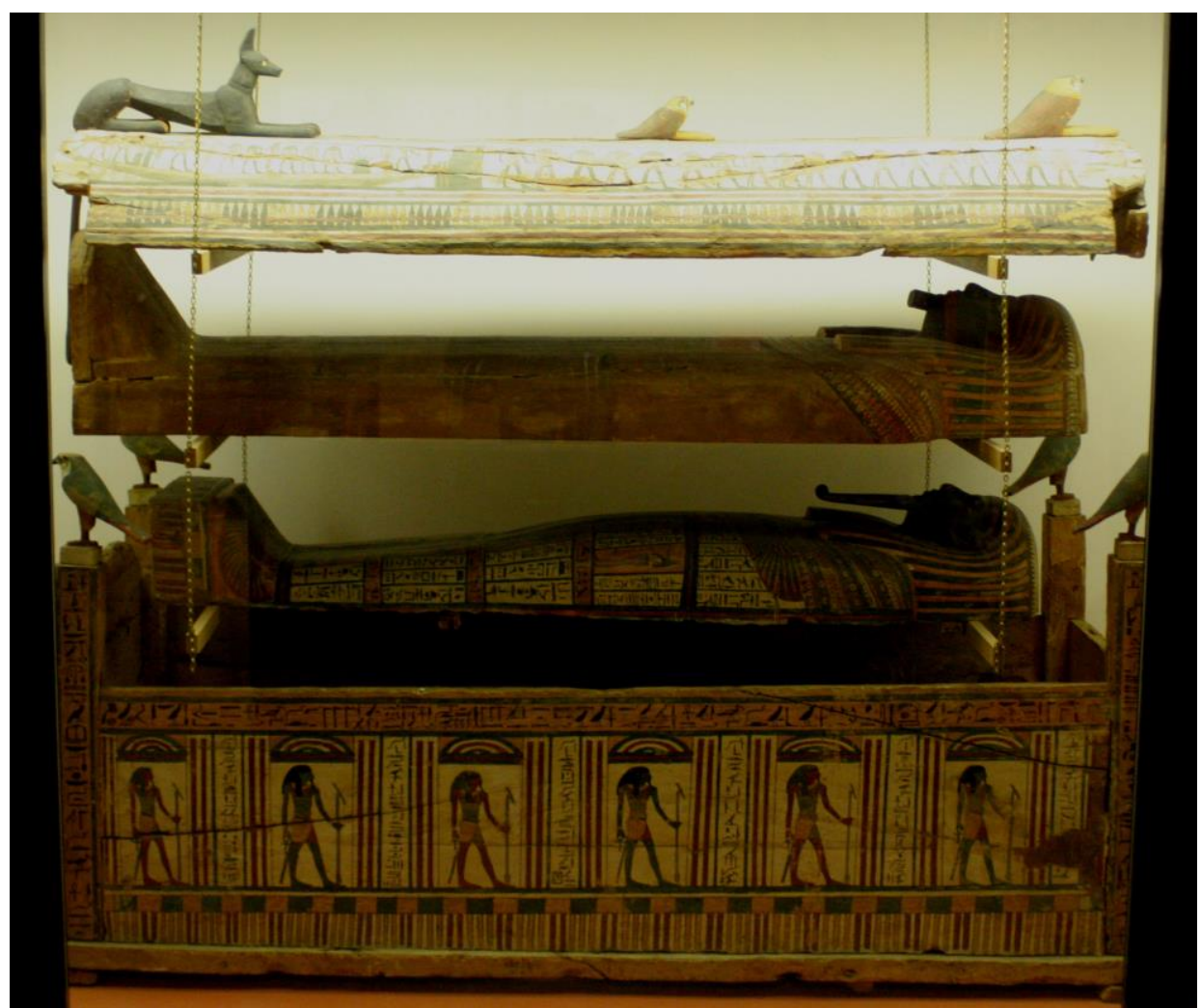

Figure 3. The coffins of Djed-Djehuty-Iuef-Ankh in Oxford (photo by D. Magdolen). 